JOURNAL OF TOURISM

AND ECONOMIC
Journal of Tourism and Economic Vol.4, No.2, 2021, Page 164-175

ISSN: 2622-4631 (print), ISSN: 2622-495X (online)

Email: jurnalapi@gmail.com

Website: http://jurnal.stieparapi.ac.id/index.php/JTEC

DOI: https://doi.org/10.36594/jtec.v4i2.125

\title{
PENGARUH KEAMANAN DAN KESELAMATAN TERHADAP CITRA DESTINASI DI OBYEK WISATA ALAM AIR TERJUN SRI GETHUK GUNUNGKIDUL
}

\author{
Fian Damasdino \\ Program Studi Pariwisata, Sekolah Tinggi Pariwisata AMPTA Yogyakarta \\ fiandamdin@gmail.com \\ Dian Afrini \\ Program Studi Pariwisata, Sekolah Tinggi Pariwisata AMPTA Yogyakarta \\ Prihatno \\ Program Studi Pengelolaan Perhotelan, Sekolah Tinggi Pariwisata AMPTA Yogyakarta
}

\begin{abstract}
This study aims to see if there is an influence between the security and safety of tourists on the image of tourist destinations at Sri Gethuk Waterfall, Gunungkidul. This study uses quantitative research methods with 100 respondents from tourists who have visited Sri Gethuk Waterfall in the last one year. Collecting data using observation, questionnaires, and library documentation. The results show that there is an influence between the security and safety of tourists simultaneously on the image of the destination, while the Coefficient of Determination Test shows that the image of a tourist destination is influenced by the security and safety of tourists by $78.1 \%$, while the remaining $21.9 \%$ is explained by other factors not examined in this study.
\end{abstract}

Keywords: Security, Safety, Destinations image 


\begin{abstract}
ABSTRAK
Penelitian ini bertujuan untuk melihat ada pengaruh antara keamaman dan keselamatan wisatawan terhadap citra destinasi wisata di Air Terjun Sri Gethuk, Gunungkidul. Penelitian ini menggunakan metode penelitian kuantitatif dengan 100 responden wisatawan yang pernah berkunjung ke Air Terjun Sri Gethuk dalam rentang waktu satu tahun terakhir. Pengumpulan data menggunakan observasi, kuersioner, dan dokumentasi pustaka. Hasil penelitian menunjukkan terdapat pengaruh antara keamanan dan keselamatan wisatawan secara simultan terhadap citra destinasi, sedangkan Uji Koefisien Determinasi menunjukkan bahwa citra destinasi wisata dipengaruhi oleh keamanan dan keselamatan wisatawan sebesar $78.1 \%$, sedangkan sisanya sebesar $21.9 \%$ dijelaskan oleh faktor lain yang tidak diteliti dalam penelitian ini.
\end{abstract}

Kata kunci : Keamanan, Keselamatan, Citra Destinasi 


\section{PENDAHULUAN}

Pariwisata merupakan mega bisnis dan merupakan bisnis yang kompleks, karena melibatkan berbagai komponen yang terdapat dalam produk pariwisata (Prihastuti \& Widayati, 2019). Menurut Diktipari.org; Prayudi, dimana pariwisata merupakan sektor bisnis "yang mendorong pertumbuhan sektor ekonomi paling cepat" (Abdullah \& Panghastuti, 2018).

Kabupaten Gunungkidul memiliki luas satu pertiga dari luas daerah induknya yakni Daerah Istimewa Yogyakarta, dengan landskap yang didominasi oleh panorama yang indah serta ekosistem karst yang membentang. Keadaan ini membuat Gunungkidul dikenal sebagai kabupaten yang memiliki potensi wisata alam menarik dan menyenangkan. Keanekaragaman destinasi wisata pada bentang karst meliputi pantai-pantai yang dikelilingi tebing karst, goa-goa dan aliran sungai di dalamnya, air terjun, bukit-bukit dan lembah karst. Destinasi wisata tersebut ada yang dikelola oleh pemerintah daerah dan ada yang dikelola oleh masyarakat sekitar salah satunya yaitu, Air Terjun Sri Gethuk.

Air terjun Sri Gethuk merupakan salah satu destinasi wisata alam yang terletak di Kecamatan Playen, Kabupaten Gunungkidul, Yogyakarta. Air terjun Sri Gethuk memiliki karakteristik daya tarik wisata alam yang berlatarkan pemandangan berupa tebing-tebing kapur dan berada di tepi sungai Oyo dengan tinggi air terjun mencapai \pm 50 meter. Air terjun Sri Gethuk memiliki keunikan tersendiri yaitu bercabang pada dua celah tebing dan muncul dari sela-sela tebing karst yang gersang dengan didukung tiga sumber mata air yang terdiri dari mata air Ngandong, Dog poh, dan Ngumbul.

Ketiga mata air ini berkumpul menjadi satu dan jatuh dari tebing bebatuan karst yang tandus mengaliri sungai oyo. Keunikannya memotivasi wisatawan untuk berkunjung, sebagian wisatawan mendapatkan referensi dari sosial media berupa foto, video, dan ulasan. Unggahan wisatawan yang telah berkunjung membuat pengguna sosial media lainnya ingin datang berkunjung. Hal ini membuat media sosial menjadi wadah bagi calon wisatawan untuk berkunjung ke Air Terjun Sri Gethuk yang nantinya menghasilkan kesan atau citra dari destinasiwisata Air Terjun Sri Gethuk.

Secara khusus penelitian ini akan melihat ada pengaruh antara keamaman dan keselamatan wisatawan terhadap citra destinasi wisata di Air Terjun Sri Gethuk, Gunungkidul. Peneliti melihat bahwa pengelolaan isu keamanan dan keselamatan di sebuah destinasi wisata sangat berkaitan dengan munculnya citra destinasi yang diterapkan pada lokasi obyek wisata. Citra destinasi yang kuat dan positif diwujudkan dengan kepuasan wisatawan yang tinggi saat melakukan kunjungan wisata, sehingga citra destinasi akan memengaruhi persepsi wisatawan terhadap unsur-unsur produk yang ditawarkan melaluipengelolaan yang dilakukan oleh sebuah destinasi. Pelaku wisata perlu memperhatikan pengelolaan keamanan dan keselamatan agar wisatawan yang berkunjung merasa aman dan nyaman. Pengelolaan keselamatan dan keselamatan dalam destinasi wisata dilakukan agar wisatawan merasa terlindungi saat berkunjung.

\section{TINJAUAN LITERATUR}

\section{Keamanan dan Keselamatan}

Aspek keamanan dan keselamatan di sebuah destinasi wisata sangat berkaitan dengan kenyamanan setiap perjalanan wisata (Hamm \& Su, 2021). Pengelolaan keamanan dan keselamatan merupakan salah satu upaya meningkatkan kunjungan dalam sebuah destinasi wisata. Keamanan dan keselamatan menjadi syarat yang sangat penting dalam industri pariwisata saat ini (Xiaobin et al., 2021). Aspek tersebut pada dua dekade terakhir telah menjadi isu yang semakin besar dan mempunyai dampak yang sangat besar terhadap keberlangsungan aktivitas perjalanan 
dan pariwisata (Kovari dan Zimanyi, 2011 : 60). Aktivitas berwisata yang memiliki risiko tinggi terjadinya kecelakaan yang dapat merugikan wisatawan sangat membutuhkan kepastian mengenai keamanan dan keselamatan (Breda \& Costa, 2006).

Menyadari pentingnya aspek keamanan dan keselamatan wisatawan, hal tersebut bukan saja semata menjadi tanggung jawab pemilik (owner) atau pengelola destinasi wisata tetapi pemangku kepentingan (stakeholder) baik daerah maupun pusat dalam memajukan pariwisatadi suatu wilayah.

Aspek keamanan dan keselamatan sangat berkaitan erat dengan citra destinasi wisata (Marine-Roig \& Huertas, 2020). Citra destinasi atau destination image adalah unsur penting bagi sebuah destinasi pariwisata, tidak hanya sebagai atribut destinasi tetapi juga kesan menyeluruh yang ditampilkan oleh destinasi. Hal ini disebabkan karena citra merupakan gambaran kondisi dari unsur-unsur yang dimiliki dalam destinasi tersebut pada kurun waktu yang relatif cukup lama (Chaulagain et al., 2021). Citra destinasi yang kuat dan positif diwujudkan dengan kepuasan wisatawan yang tinggi saat melakukan kunjungan wisata, sehingga citra destinasi akan memengaruhi persepsi wisatawan terhadap unsur-unsur produk yang ditawarkan melalui pengelolaan yang dilakukan oleh sebuah destinasi. Selain itu aspek kemanan dan keselamatan berperan dalam memberikan rasa aman dan nyaman bagi wisatawan untuk berkunjung.

\section{Citra Destinasi}

Citra destinasi merupakan gambaran atau persepsi individu terhadap suatu daerah, atauwilayah tertentu (Lu \& Atadil, 2021). Citra destinasi adalah persepsi yang menyeluruh mengenai suatu daerah, yang terbentuk dari proses informasi dari berbagai sumber, padarentang waktu tertentu (MarineRoig \& Huertas, 2020). Menurut Blain et. al (2005), citra destinasi merupakan kegiatan pemasaran yang mempromosikan keunggulan dan image positif suatu daerah untuk memberikan pengaruh kepada wisatawan agar mengunjungi daerah tersebut.

Citra adalah seperangkat keyakinan ide dan kesan yang dimiliki seseorang tehadap suatu objek (Simpson et al., 2016). Citra sebagai kesan yang diperoleh dengan pengetahuan dan pengalaman seseorang tentang sesuatu (Carballo et al., 2021). Pembentukan citra destinasi menurut (Tocquer \& Zins, 2004), antara lain: Vague and unrealistic image, Distrortion of the image, Improved image, Resulting image. Dimensi Citra Destinasi menurut Lopes et al. (2011) memiliki 2 (dua) dimensi, yaitu Cognitive destination image dan Affective destination image. Peneliti lain Echtner \& Brent Ritchie (1993), destination image secara sederhana mengacu pada 4 komponen berikut:

1) Atribut karakteristik fungsional, atribut fisik yang bersifat fungsional yang berhubungan dengan sebuah tempat sebagai tujuan wisata. Atribut ini mencakup : (a) kondisi obyek wisata, (b) kondisi jumlah parkir, (c) tingkat harga dari obyek wisata, (d) iklim, (e) kondisi infrastruktur, dan (f) kondisi destinasi .

2) Karakteristik fungsional holistik, atribut fisik yang bersifat fungsional dan holistik yang berhubungan dengan sebuah tempat tujuan wisata. Atribut ini mencakup : (a) kondisi kebersihan, (b) keamanan pribadi, dan (c) kemudahan akses.

3) Atribut karakteristik psikologis, atribut fisik yang bersifat psikologis yang berhubungan dengan sebuah tempat tujuan wisata. Atribut ini mencakup : (a) keramah tamahan penduduk, (b) kelestarian lingkungan, dan (c) reputasi.

4) Karakteristik psikologis-holistik, atribut fisik yang bersifat psikologis dan holistik yang berhubungan dengan sebuah tempat tujuan wisata. Atribut ini mencakup : (a) perasaan umum dari pengunjung, dan (b) pengembangan wisata.

Penelitian yang berkaitan dengan keamanan dan keselamatan wisatawan apabila dikaitkan dengan citra destinasi belum banyak 
dilakukan. Pada penelusuran bibliometrik pada gambar 1 di bawah ini menunjukkan peta riset dalam 5 tahun terakhir yang membahas isu yang sama. Diskusi mengenai kepariwisataan apabila dikaji menggunakan pendekatan keamanan, keselamatan, dan citra destinasi menunjukkan titik yang masih kecil dan sangat jauh dari pusat episentrum pariwisata. Hal ini menunjukkan diskusi dan publikasi pada ranah ini masih sedikit dan belum banyak dilakukan oleh para penulis.

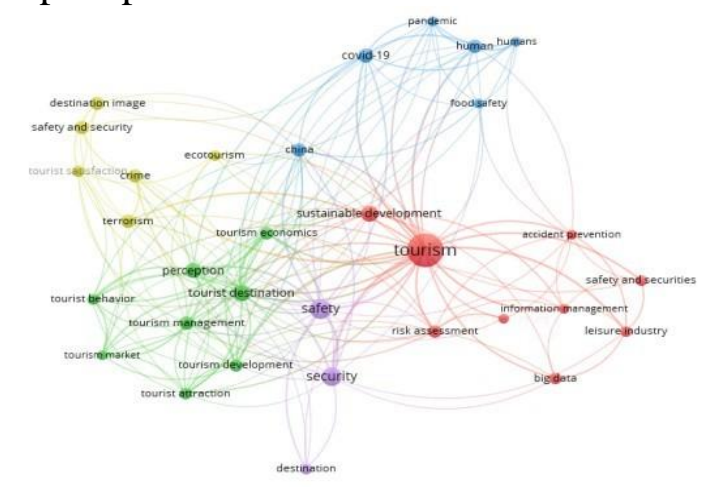

Gambar 1 Penelurusan Bibliometrik 5 tahun terakhir

Sumber: VOS Viewer, 2021

\section{METODE PENELITIAN}

Penelitian ini merupakan penelitian kuantitatif dengan maksud memperoleh data yang berbentuk angka dengan tujuan untuk menguji hipotesis yang telah ditetapkan. Menurut Umar, pengumpulan data dilakukan dengan menggunakan data primer yang didapat dari hasil wawancara dan pengisian kuesioner (Ambarwati \& Isnugroho, 2018). Waktu penelitian dimulai dari bulan Maret hingga Oktober 2021. Populasi dalam penelitian ini adalah seluruh wisatawan yang pernah berkunjung ke Air Terjun Sri Gethuk. Data primer diperoleh melalui observasi lapangan secara langsung dan kuisioner dalam bentuk google form disebarkan kepada responden. Peneliti menggunakan sampling purposive karena tidak semua sampel dalam populasi memiliki kriteria yang sesuai untuk menjadi sampel dalampenelitian ini. Sehingga dengan pertimbangan tertentu, peneliti menentukan kriteria untuk mendapatkan sampel yang representatif. Kriteria tersebut diantaranya: (1) Responden sudah pernah berkunjung ke Air Terjun Sri Gethuk minimal 1 kali. (2) Responden berkunjung dalam rentang waktu 1 (satu) tahun terakhir. Sedangkan data sekunder menggunakan dokumentasi pustaka dari data statistik kepariwisataan Daerah Istimewa Yogyakarta maupun Kabupaten Gunungkidul.

Dalam penelitian ini, variabel independent (bebas) meliputi keamanan (X1) dan keselamatan (X2) wisatawan di Air Terjun Sri Gethuk. Sedangkan variabel dependent (variabel terikat) adalah citra destinasi (Y).

Tabel 1 Definisi Operasional dan Konseptual Penelitian

\begin{tabular}{|c|c|c|}
\hline Variabel Penelitian & Definisi & Indikator \\
\hline KeamananWisatawa & Rasa aman bagi wisatawan & 1. Tidak menggangguwisatawan \\
\hline $\mathrm{n}(\mathrm{X} 1)$ & dan keberlangsungan & 2. Saling melindungiwisatawan \\
\hline & kegiatankepariwisataan & 3. Memelihara keamanan \\
\hline & & lingkungan \\
\hline & & 4. Membantu memberiinformasi \\
\hline & & kepada wisatawan \\
\hline & & 5. Menjaga lingkungan yang bebas dari \\
\hline & & bahayapenyakit menular \\
\hline & & $\begin{array}{l}\text { 6. Meminimalisir risikokecelakaan } \\
\text { dalam penggunaan fasilitas publik }\end{array}$ \\
\hline
\end{tabular}




\begin{tabular}{|c|c|c|}
\hline $\begin{array}{l}\text { KeselamatanWisata } \\
\text { wan (X2) }\end{array}$ & $\begin{array}{l}\text { Kepastian } \begin{array}{l}\text { tidak } \\
\text { adanya }\end{array} \\
\text { gangguan dari pihak } \\
\text { manapun }\end{array}$ & $\begin{array}{l}\text { 1. Pekerjaan/perekayasa } \\
\text { 2. Memperkuat } \\
\text { 3. Pendidikan } \\
\text { 4. Tindakan } \\
\text { 5. Kesiapan bahaya }\end{array}$ \\
\hline Citra Destinasi (Y & $\begin{array}{l}\text { Gambaran atau persepsi } \\
\text { individu terhadap suatu } \\
\text { daerah atau wilayah } \\
\text { tertentu }\end{array}$ & $\begin{array}{l}\text { 1. Atraksi wisata } \\
\text { 2. Fasilitas dasar } \\
\text { 3. Aksesbilitas } \\
\text { 4. Lingkungan alam } \\
\text { 5. Suatu yangmenyenangkanpada destinasi } \\
\text { 6. Kondisi aman padadestinasi }\end{array}$ \\
\hline
\end{tabular}

Sumber: Analisa Penulis, 2021

Dalam penelitian ini, terdapat 2 (dua) hipotesa yang akan diuji:

- Ha1: Diduga terdapat pengaruh antara aspek pengelolaan keamanan dan keselamatan wisatawan terhadap citra destinasi di Air Terjun Sri Gethuk, Gunungkidul.

- Ha2: Diduga keamanan adalah aspek yang memberi pengaruh lebih terhadap citra destinasi di Air Terjun Sri Gethuk, Gunungkidul.

\section{HASIL DAN PEMBAHASAN}

\section{Deskripsi Objek Penelitian}

Air Terjun Sri Gethuk terletak di Dusun Menggoran, Desa Bleberan, Kecamatan Playen, Kabupaten Gunungkidul. Saat ini dikelola oleh Kelompok Sadar Wisata (POKDARWIS) Bleberan, yang juga mengelola wisata lain yang berada di Desa Bleberan. Air Terjun Sri Gethuk memiliki keunikan berupa terdapat cabang pada dua celah tebing dan muncul air dari sela-sela tebing karst yang gersang, berasal dari ketiga sumber mata air yaitu mata air Ngandong, Dong Poh, dan Ngumbul dengan debit air rata-rata 30-60 liter perdetik. Ketinggian air terjun ini mencapai \pm 50 meter, ketinggian grojogan \pm 1 meter dan kedalaman sungai oyo yang bervariasi yaitu 5-10 meter. Sungai Oyo yang mengalir di kawasan ini tidak pernah kering meskipun musim kemarau dan warna airpun lebih jernih dibandingkan pada musim hujan warna air menjadi keruh. Air Terjun Sri Gethuk menjadi atraksi utama pada destinasi ini, selain itumenjadi spot foto utama bagi wisatawan yang berkunjung.

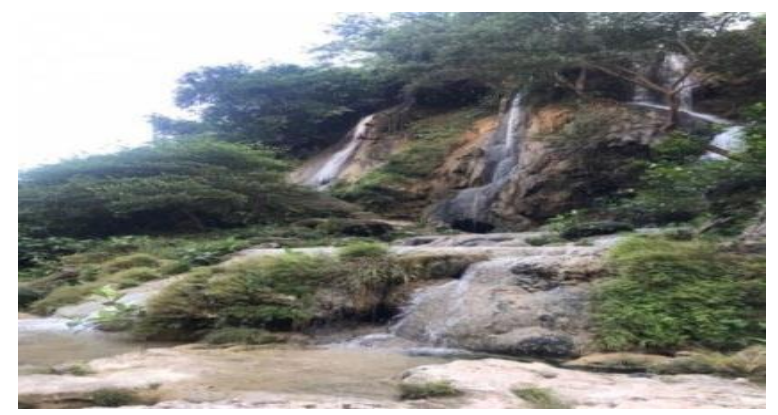

Gambar 2 Panorama Air Terjun Sri Gethuk Sumber: Dokumentasi lapangan, 2021

Perahu menjadi salah satu atraksi wisata, Wisatawan yang ingin menuju air terjun dapat menggunakan perahu dengan membayar sebesar Rp.10.000 per orangnya dan terdapat pemandu di perahu untuk mengawasi wisatawan agar meminimalisisr terjadinya risiko kecelakaan. Amenitas yang dimiliki Air Terjun Sri Gethuk sudah cukup lengkap, diantaranya tersedia toilet, tempat sampah, ruang ganti, mushola, warung makan, warung oleh-oleh, area parkir, papan himbauan, papan petunjuk arah, tempat cuci tangan, posko keamanan, posko informasi dan tempat penyewaan pelampung. Penyewaan pelampung ditujukan kepada wisatawan yang inginberenang di sungai oyo diwajibkan menyewa pelampung untuk menjaga keselamatan dengan membayar 
sebesar Rp.20.000 untuk satu unit pelampungnya. Satu pelampung dapat menampung berat $\pm 80-100 \mathrm{~kg}$.

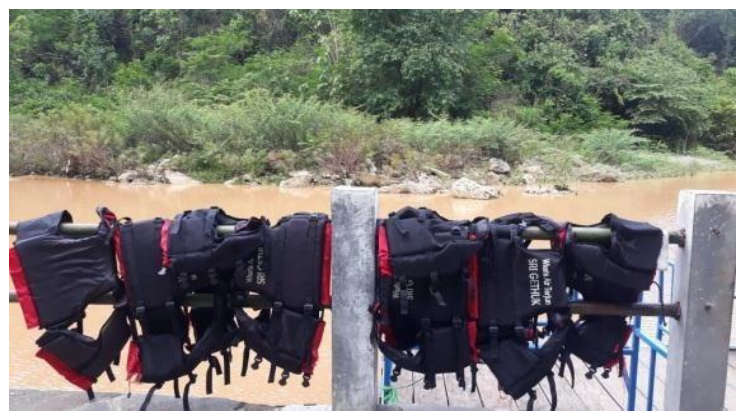

Gambar 3 Amenitas Penyewaan Pelampung Sumber: Dokumentasi lapangan, 2021

Aksesbilitas menuju Air Terjun Sri Gethuk sudah baik disertai pentunjuk arah yang jelas. Kondisi jalan ini sudah teraspal baik, hanya ketika memasuki pintu gerbang destinasi $2 \mathrm{~km}$ masih berupa jalan berbatu putih (bukan jalan beraspal). Namun jalan belum teraspal menjadi daya tarik tersendiri bagi wisatawan karena menambah nilai adventure dengan dikelilingi tanaman kayu putih disekitarnya. Selain itu jalan ini dapat dilalui kendaraan roda dua maupun roda empat, dilakukan jalan satu arah untuk memudahkan wisatawan saat berkunjung. Air Terjun Sri Gethuk terletak 38 km dari pusat Kota Yogyakarta yang dapat ditempuh \pm 1 jam 20 menit dengan menggunakan kendaraan pribadi.

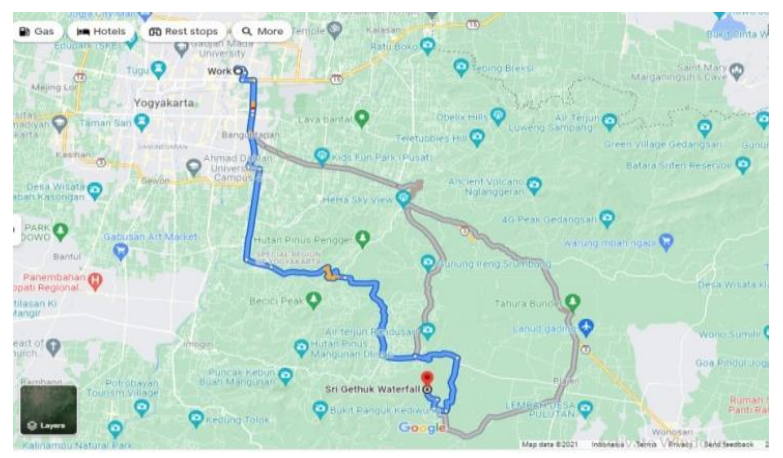

Gambar 4 Peta Lokasi dari Pusat Kota Sumber: googlemap, 2021
Dari data demografi pada gambar 5 berikut menunjukkan mayoritas wisatawan yang berkunjung berjenis kelamin perempuan terdapat sebanyak $68 \%$, sedangkan wisatawan yang berjenis laki-laki berjumlah $32 \%$. Hal ini menunjukkan bahwa yang berkunjung didominasi oleh perempuan dibandingkan laki-laki, karena perempuan suka mengikuti trend yang terbaru dan membagikan momen di sosial media yang dapat mempengaruhi masyarakat lainnya.

\section{Hasil Uji Berdasarkan Jenis Kelamin}

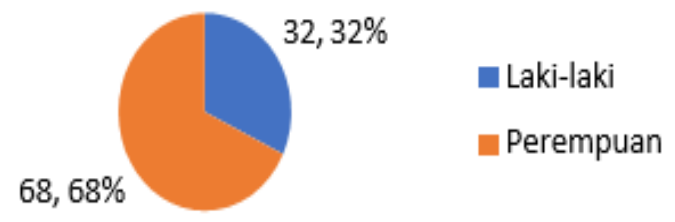

Gambar 5 Diagram Tentang Jenis Kelamin Responden

Sumber: Analisis Peneliti, 2021

Berdasarkan gambar 6 dapat diketahui bahwa wisatawan dari luar Yogyakarta sebanyak 91\% sedangkan wisatawan yang berasal dari Yogyakarta sebanyak 9\%. Hal ini menunjukkan bahwa wisatawan yang berkunjung dari luar daerah lebih banyak, karena penasaran dengan Air terjun Sri Gethuk yang sempat viral di media sosial.

\section{Hasil Uji Berdasarkan Asal Wisatawan}

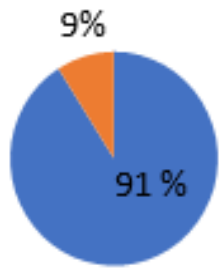

Luar Kota

- Dalam Kota

Gambar 6 Diagram Tentang Asal Responden

Sumber: Analisis Peneliti, 2021

\section{Karakteristik Responden}


Berdasarkan rentang usia pada gambar 7, dapat diketahui bahwa pada wisatawan berusia 17-22 tahun mempunyai frekuensi sebanyak $58 \%$, selanjutnya pada usia $23-28$ tahun mempunyai frekuensi sebanyak $37 \%$, sedangkan usia di atas 36 tahun sebanyak $3 \%$, dan yang paling sedikit berkunjung adalah wisatawan dengan usia 29-34 tahun sebanyak 2\%. Hal ini menunjukkan bahwa banyaknya wisatawan muda yang masih memiliki jiwa adventure dan banyakmencoba hal yang menantang. Hasil Uji Berdasarkan Usia Wisatawan

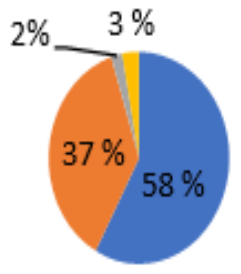

\section{7-22 Tahun 23-28 Tahun 29-34 Tahun 1 $>36$ Tahun}

Gambar 7 Diagram Tentang Usia Responden

Sumber: Analisis Peneliti, 2021

\section{Uji Regresi Linear Berganda}

Hasil perhitungan pada table 2 di bawah ini menunjukkan nilai konstanta dari hasil penelitian sebesar 5.366 menunjukkan nilai positif, hal ini menjelaskan bahwa walaupun tidak ada variabel keamanan dan keselamatan maka besarnya tingkat destinasi wisata adalah 5.366. Nilai koefisien regresi untuk variable keamanan (X1) sebesar 0.178 menunjukkan nilai yang positif, hal ini menjelaskan apabila variabel keamanan meningkat satu point maka tingkat destinasi wisata naik sebesar 0.178. Nilai koefisien regresi untuk variable keselamatan (X2) sebesar 0.852 menunjukkan nilai yang positif, hal ini menjelaskan apabila variabel keselamatan meningkat satu point maka tingkat destinasi wisata naik sebesar 0.852. Adanya pengaruh positif yang ditunjukkan pada hasil penelitian ini, artinya bahwa variabel keamanan dan keamanan dengan citra destinasi menunjukkan pengaruh yang searah, sehingga variabel kemanan dan keselamatan yang meningkat maka citra destinasi wisata akan meningkat.

Tabel 2 Hasil Uji Regresi Linear Berganda

\begin{tabular}{|c|c|c|c|c|c|c|c|c|}
\hline \multirow{2}{*}{ Mode } & & \multicolumn{2}{|c|}{ Unstandardized Coefficients } & \multirow{2}{*}{$\begin{array}{c}\begin{array}{c}\text { Standardized } \\
\text { Coefficients }\end{array} \\
\text { Beta }\end{array}$} & \multirow[b]{2}{*}{$t$} & \multirow[b]{2}{*}{ Sig. } & \multicolumn{2}{|c|}{ Collinearity Statistics } \\
\hline & & B & Std. Error & & & & Tolerance & VF \\
\hline \multirow[t]{3}{*}{1} & (Constant) & 5.366 & 1.802 & & 2.977 & .004 & & \\
\hline & Keamanan & .178 & .070 & .238 & 2.541 & .013 & .251 & 3.981 \\
\hline & Keselamatan & .852 & .119 & .672 & 7.166 & .000 & .251 & 3.981 \\
\hline
\end{tabular}

Sumber: Analisis Peneliti, 2021

\section{Uji Simultan (Uji F)}

Berdasarkan hasil di atas diketahui nilai signifikan untuk pengaruh keamanan dan keselamatan wisatawan secara simultan terhadap citra destinasi wisata adalah sebesar $0.000<0.05$, serta nilai $\mathrm{F}$ hitung $177.807>$ 3.09. Hasil uji di atas dapat disimpulkan bahwa variabel keamanan dan keselamatan berpengaruh secara simultan terhadap variabel citra destinasi wisata. Hasil uji f di atas membuktikan bahwa $\mathrm{Ha}_{1}$ yang berbunyi "diduga terdapat pengaruh yang signifikan antara aspek keamanan dan keselamatan wisatawan terhadap citra destinasi wisata" diterima.

\begin{tabular}{|c|c|c|c|c|c|c|}
\hline \multicolumn{2}{|c|}{ Model } & $\begin{array}{l}\text { Sum of } \\
\text { Squares }\end{array}$ & df & Mean Square & $\mathrm{F}$ & Sig. \\
\hline \multirow[t]{3}{*}{1} & Regression & 2098.191 & 2 & 1049.096 & 177.807 & $.000^{\mathrm{b}}$ \\
\hline & Residual & 572.319 & 97 & 5.900 & & \\
\hline & Total & 2670.510 & 99 & & & \\
\hline
\end{tabular}

Sumber: Analisis Peneliti, 2021

\section{Uji Parsial (Uji T)}

Berdasarkan

tabel 4, aspek keamanan memiliki nilai $\mathrm{T}_{\text {hitung }}$ sebesar 2.541, maka $2.541>1.984$ dengan nilai signifikan $0.013<0.05$. Berdasarkan angka di atas dapat dilihat bahwa keamanan wisatawan berpengaruh signifikan terhadap citra destinasi wisata. Aspek keselamatan memiliki nilai $\mathrm{T}_{\text {hitung }}$ sebesar 7.166 , maka $7.166>1.984$ dengan nilai signifikan 0.000 $<0.05$. berdasarkan angka di atas dapat dilihat bahwa keselamatan wisatawan 
berpengaruh terhadap citra destinasi. Dari hasil analisis terhadap aspek keamanan dan keselamatan wisatawan diketahui aspek yang memiliki pengaruh lebih besar terhadap citra destinasi wisata adalah keselamatan wisatawan. Hal ini dikarenakan keselamatan memiliki nilai signifikan $0.000<0.05$ pada taraf kepercayaan 95\%. Selain itu keselamatan memiliki nilai Beta sebesar 0.672. Berdasarkan hasil tersebut maka $\mathrm{Ha}_{2}$ yang berbunyi "diduga keamanan adalah aspek yang memberi pengaruh lebih terhadap citra destinasi di Air Terjun Sri Gethuk, Gunungkidul" ditolak.

Tabel 4 Hasil Uji T (Parsial)

\begin{tabular}{|c|c|c|c|c|c|c|c|c|}
\hline \multirow[b]{2}{*}{ Model } & & \multicolumn{2}{|c|}{ Unstandardized Coefficients } & \multirow{2}{*}{$\begin{array}{c}\begin{array}{c}\text { Standardized } \\
\text { Coefficients }\end{array} \\
\text { Beta } \\
\end{array}$} & \multirow[b]{2}{*}{$t$} & \multirow[b]{2}{*}{ Sig. } & \multicolumn{2}{|c|}{ Collinearity Statistics } \\
\hline & & B & Std. Error & & & & Tolerance & VIF \\
\hline \multirow[t]{3}{*}{1} & (Constant) & 5.366 & 1.802 & & 2.977 & .004 & & \\
\hline & Keamanan & .178 & .070 & .238 & 2.541 & .013 & .251 & 3.981 \\
\hline & Keselamatan & .852 & .119 & .672 & 7.166 & .000 & .251 & 3.981 \\
\hline
\end{tabular}

Sumber: Analisis Peneliti, 2021

\section{Uji Koefisien Determinasi $\left(\mathbf{R}^{\mathbf{2}}\right)$}

Berdasarkan tabel 5 diketahui Koefisien Determinasi $\left(\mathrm{R}^{2}\right)$ sebesar 0.781 besarnya angka tersebut sama dengan $78.1 \%$. sesuai dengan acuan untuk mengetahui besaran nilai korelasi antarvariabel, nilai $\mathrm{r}^{2}$ (78.1\%) berada pada $0.70 \leq r<0.90$ sehingga diketahui korelasi antar variabel penelitian ini kuat. Hasil dari uji ini menunjukkan bahwa citra destinasi wisata dipengaruhi oleh keamanan dan keselamatan wisatawan sebesar $78.1 \%$, sedangkan sisanya sebesar $21.9 \%$ dijelaskan oleh faktor lain yang tidak diteliti dalam penelitian ini.

Tabel 5 Hasil Uji Koefisien Determinasi

(R2)

Model Summary

\begin{tabular}{|l|l|r|r|r|r|}
\hline Model & R & R Square & $\begin{array}{c}\text { Adjusted R } \\
\text { Square }\end{array}$ & $\begin{array}{l}\text { Std. Error of } \\
\text { the Estimate }\end{array}$ & $\begin{array}{l}\text { Durbin- } \\
\text { Watson }\end{array}$ \\
\hline 1 & $.886^{\mathrm{a}}$ & .786 & .781 & 2.42903 & 1.957 \\
\hline
\end{tabular}

a. Predictors: (Constant), Keselamatan, Keamanan

b. Dependent Variable: Citra Destinasi

Sumber: Analisis Peneliti, 2021

\section{Pengaruh Keamanan Terhadap Citra Destinasi Wisata}

Hasil dari uji t dapat diketahui bahwa pengaruh variabel X1 terhadap Y sebesar $2.541>1.984$ dengan nilai signifikan $0.013<$ 0.05. Nilai tersebut membuktikan hipotesis diterima, sehingga dapat dikatakan bahwa "ada pengaruh keamanan terhadap citra destinasi wisata". Keamanan adalah sebuah keadaan aman dan ketentraman seseorang atau kelompok orangterhadap risiko bahaya yang timbul karena faktor lingkungan (Suharto, 2016 : 292). Keamanan merupakan rasa aman bagi wisatawan dan keberlangsungan kegiatan kepariwisataan, sehingga wisatawan merasa tidak cemas dan dapat menikmati kunjungan ke suatu destinasi wisata. sehingga dapat dikatakan bahwa semakin tinggi tingkat keamanan destinasi maka akan semakin meningkat pula citra destinasi.

Penelitian ini dilakukan pada saat pandemi, untuk meminimalisir penularan virus covid- 19 pihak pengelola menerapkan protokol kesehatan sesuai anjuran pemerintah pada destinasi wisata, seperti melakukan scrining melalui pengecekan suhu, memeriksa wisatawan untuk tetap menggunkan masker, menyediakan sarana cuci tangan atau handsanitizer, mengarsipkan data wisatawan melalui kartu tanda penduduk (KTP) dan nomer telpon, serta Air Terjun Sri Gethuk menetapkan tutup satu hari untuk sterilisasi yaitu di hari Jum'at berlaku hingga saat ini. Hal tersebut memberikan rasa aman saat berwisata, rasa aman merupakan salah satu faktor terciptanya citra destinasi karena dengan amannya kondisi suatu destinasi akan membuat wisatawan nyaman dan mengurangi kekhawatirannya, maka terciptanya citra yang positif.

\section{Pengaruh Keselamatan Terhadap Citra Destinasi}

Hasil dari uji t dapat diketahui bahwa pengaruh variabel X2 terhadap Y sebesar 
maka $7.166>1.984$ dengan nilai signifikan $0.000<0.05$. Nilai tersebut dapat membuktikan hipotesis diterima. Sehingga dapat dikatakan bahwa "ada pengaruh keselamatan terhadap citra destinasi wisata". Keselamatan merupakan keadaan selamat atau keadaan seseorang atau sekelompok orang untuk mendapatkan kesejahteraan dan kebahagiaan. Jaminan keselamatan merupakan faktor yang menjadi pertimbangan wisatawan dalam memilih destinasi wisata yang akan dikunjungi. Oleh karena itu, upaya peningkatan keselamatan dianggap sebagai salah satu upaya yang sangat tepat dalam menciptakan citra suatu destinasi yang positif.

Upaya keselamatan yang dilakukan oleh pengelola di destinasi Air Terjun Sri Gethuk dengan menambah posko keselamatan di dekat area sungai dan air terjun, perbaikian jalur tracking dan tangga pendakian, dan penanda jalur evakuasi. Upaya lain dilakukan denganmenjaga dan membersihkan lingkungan area Air Terjun Sri Gethuk untuk tetap menciptakan suasana yang asri, pengecekan pada atraksi maupun fasilitas bertujuan untuk menjaga kondisi agar tetap

\section{Pengaruh Keamanan dan Keselamatan Secara Simultan terhadap Citra Destinasi Wisata di Air Terjun Sri Gethuk, Gunungkidul}

Hasil analisis Uji $F$ yang telah dilakukan memperoleh nilai $F_{\text {hitung }}$ sebesar $177.807>\mathrm{F}_{\text {tabel }} 3.09$ dengan tingkat signifikan sebesar $0.000<0.05$. berdasarkan nilai tersebut dapat disimpulkan bahwa keamanan dan keselamatan wisatawan berpengaruh secara simultan terhadap variabel citra destinasi wisata, hasil Uji $F$ membuktikan bahwa $\mathrm{Ha}_{1}$ yang berbunyi "diduga ada pengaruh antara aspek keamanan dan keselamatan terhadap citra destinasi wisata di Air Terjen Sri Gethuk, Gunungkidul” diterima. Koefiensi
Determinasi yang telah dianalisis terdapat nilai sebesar 0.781 besarnya angka tersebut sama dengan $78.1 \%$. sesuai acuan untuk menegtahui besaran nilai korelasi anatar variabel, nilai r2 $(78.1 \%)$ berada pada $0.70 \leq$ $r<0.90$ sehingga diketahui korelasi antar variabel penelitian ini kuat.

Peneliti berasumsi bahwa dengan korelasi antar variabel yang kuat disebabkan karena destinasi Air Terjun Sri Gethuk merupakan jenis wisata minat khusus yang keamanan dan keselamatannya berperan penting dalam memberikan kenyamanan kepada wisatawan saat berwisata. Hasil dari uji ini menunjukkan bahwa citra destinasi wisata dipengaruhi oleh keamanan dan keselamatan wisatawan sebesar $78.1 \%$, sedangkan sisanya sebesar $21.9 \%$ dijelaskan oleh faktor lain yang tidak diteliti dalam penelitian ini.

\section{Variabel yang lebih berpengaruh antara keamanan dan keselamatan wisatawan terhadap citra destinasi.}

Hasil uji parsial (uji t) menunjukkan bahwa nilai signifikan dengan $\mathrm{p}$ value 0.000 jauh lebih kecil dari alpha $(0.000<0.05)$. Keselamatan memiliki nilai Beta 0.672 lebih besar dibandingkan nilai Beta keamanan yang memiliki nilai Beta sebesar 0.238 dengan demikian Ha2 ditolak dan dapat disimpulkan bahwa keselamatan memberi pengaruh lebih terhadap citra destinasi wisata dengan pola hubungan positif. Pengelola destinasi Air Terjun Sri Gethuk sudah memaksimalkan pengelolaan keselamatan untuk wisatawannya. Tersedianya asuransi bagi wisatawan, papan informasi, himbauan, peralatan $\mathrm{p} 3 \mathrm{k}$, dan pengawasan intensif merupakan bentuk tanggungjawab yang dilakukan oleh pengelola. Hal tersebut dilakukan untuk memberikan rasa aman kepada wisatawan yang berkunjung, wistawan merasa senang, tenang, dan nyaman akanmenciptakan kesan yang baik serta citra yang positif. 
Sehubungan dengan Citra destinasi yang merupakan suasana menyenangkan di destinasiemosi atau perasaan seseorang yaitu wisatawan mengenai suatu destinasi, dibagi tiga yaitu, destinasi wisata yang menyenangkan akan mengundang wisatawan untuk berkunjung, amannya kondisi suatu destinasi akan membuat wisatawan nyaman dan mengurangi kekhawatiran, layaknya suatu destinasi wisata akan membuat wisata merasa nyaman.

\section{KESIMPULAN}

Berdasarkan hasil analisis yang telah dilakukan terhadap seluruh data penelitian, dapat ditarik kesimpulan: terdapat pengaruh antara keamanan dan keselamatan wisatawan secara simultan terhadap citra destinasi. Uji Koefisien Determinasi menunjukkan bahwa citra destinasi wisata dipengaruhi oleh keamanan dan keselamatan wisatawan sebesar 0.781 atau $78.1 \%$, sedangkan sisanya sebesar $21.9 \%$ dijelaskan oleh faktor lain yang tidak diteliti dalam penelitian ini.

Berdasarkan pada hasil penelitian, maka saran yang diberikan yaitu : Pengelola destinasi wisata Air Terjun Sri Gethuk diharapkan mempertahankan kualitas pengelolaan keamanan dan keselamatan untuk memberikan rasa aman kepada wisatawan yang nantinya akan tercipta citra yang positif bagi destinasi dan diharapkan akan terus meningkatkan jumlah kunjungan; Pengelola bisa meningkatkan kualitas atraksi, amenitas, dan aksesbilitas dengan dilakukannya pemeliharaan, pengecekan, dan perawatan secara berkala untuk menjaga kualitas, seperti mengecek keadaan fisik perahu, membersihkan lumut yang berada disekitaran grojokan sebagai upaya meminimalisir risiko kecelakaan saat berwisata; Disarankan kepada masyarakat untuk konsisten mendukung dalam mengembangkan destinasi dengan bersamasama menjaga keamanan dan kenyamanan lingkungan di area sekitar destinasi Air Terjun Sri Gethuk; Disarankan kepada pemerintah daerah untuk konsisten memberi dukungan melalui antuan secara materil untuk mengembangkan fasilitas maupun pelatihan bagi Sumber Daya Manusia di destinasi Air Terjun Sri Gethuk.

\section{DAFTAR PUSTAKA}

Abdullah, R., \& Panghastuti, T. (2018). Analisis Hubungan Antara Bangunan Bersejarah, Mitos, Budaya Masyarakat Lokal Dengan Motivasi Wisatawan Berkunjung Di Daya Tarik Wisata Tamansari Yogyakarta. Journal of Tourism and Economic, 1(1), 38-47.

Ambarwati, S., \& Isnugroho, E. (2018). Pengaruh Perceived Risk, Cost Saving, Dan Time Saving Terhadap Kepuasan Pelanggan Pada Pembelian Tiket Pesawat Online Di Situs Www.Tiket2.Com. Journal of Tourism and Economic, 1(1), 10-18.

Blain, C., Levy, S.E. \& Ritchie, J.R.B. (2005). Destination branding: insights and practices from destination management organisations. Journal of Travel Research, 43, 328-338. doi: $10.1177 / 0047287505274646$.

Breda, Z., \& Costa, C. (2006). Safety and Security Issues Affecting Inbound Tourism in the People's Republic of China. In Tourism, Security and Safety. Elsevier Inc. https://doi.org/10.1016/b978-0-75067898-8.50017-5

Carballo, R. R., León, C. J., \& Carballo, M. M. (2021). The impact of terrorist attacks in cities on the relationship between tourists' risk perception, destination image and behavioural intentions. Cities, 119(August 2020). https://doi.org/10.1016/j.cities.2021.10 3382 
Chaulagain, S., Jahromi, M. F., \& Fu, X. (2021). Americans' intention to visit Cuba as a medical tourism destination: A destination and country image perspective. Tourism Management Perspectives, 40(August 2020), 100900.

https://doi.org/10.1016/j.tmp.2021.100 900

Echtner, C. M., \& Ritchie, J. B. (1993). The measurement of destination image: An empirical assessment. Journal of travel research, 31(4), 3-13.

Hamm, D., \& Su, C.-H. (Joan). (2021). Managing tourism safety and risk: Using the Delphi expert consensus method in developing the event tourism security self-beliefs scale. Journal of Hospitality and Tourism Management, 49(August), 364-374. https://doi.org/10.1016/j.jhtm.2021.10. 001

Lopes Cardozo, T. A. (2011). Future teachers and social change in Bolivia: Between decolonisation and demonstration. DelftEburon.

Lu, Q., \& Atadil, H. A. (2021). Do you dare to travel to China? An examination of China's destination image amid the COVID-19. Tourism Management Perspectives, 40(August), 100881. https://doi.org/10.1016/j.tmp.2021.100 881

Marine-Roig, E., \& Huertas, A. (2020). How safety affects destination image projected through online travel reviews. Journal of Destination Marketing and Management, 18(August).

https://doi.org/10.1016/j.jdmm.2020.1 00469

Prihastuti, Y., \& Widayati, E. (2019). Analisis Pengaruh Marketing Mix Terhadap Keputusan Pembelian (Studi Kasus Pada Pt. Tunas Indonesia Tours \& Travel Cabang Yogyakarta) Yunita.
Journal of Tourism and Economic, 2(1), 66-75.

Simpson, J. J., Simpson, P. M., \& CruzMilán, O. (2016). Attitude towards immigrants and security: Effects on destination-loyal tourists. Tourism Management, 57, 373-386. https://doi.org/10.1016/j.tourman.2016 .06 .021

Tocquer, G. E., \& Zins, M. (2004). Marketing do Turismo, Instituto Piaget. World Tourism Organization, Portugal. Xiaobin, M., Biao, S., Guolin, H., Xing, Z., \& Li, L. (2021). Evaluation and spatial effects of tourism ecological security in the Yangtze River Delta. Ecological Indicators, 131, 108190. https://doi.org/10.1016/j.ecolind.2021. $\underline{108190}$ 